\title{
Singing and Worship in an Anglican Church Liturgy in Egba and Egba West Dioceses, Abeokuta, Nigeria
}

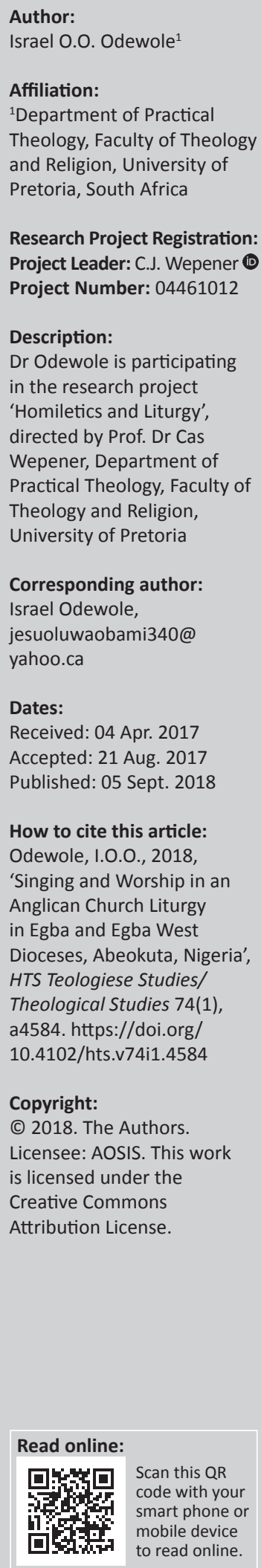

This article looks briefly at the origin or history, nature and emerging trends with regard to the singing and worship in Anglican Church Liturgy in Egba and Egba West Dioceses in the ancient metropolitan city of Abeokuta, Nigeria. The article analyses the data collected from oral interviews using atlas.ti coding method. The data are presented partly by way of frequency tables and charts. The study used qualitative approaches and conducted self-administered interviews on the major leaders, worship leaders or choir members and key lay members of the selected Anglican churches in Abeokuta. The article presents all the narratives from my sample population of the selected churches.

\section{Introduction}

This article looks briefly at the origin or history, nature and emerging trends with regard to the singing and worship in Anglican Church Liturgy in the ancient metropolitan city of Abeokuta, Nigeria. The growth and development of gospel or Christian music as a commercial product has created a market for singers and instrumentalists and this has created challenges in the Anglican Church in Abeokuta, resulting in a lack of stable and dedicated personnel in the area of instrumentalists to handle its singing and praise worship. Some of the challenges also include financial constraints, division among the church members because of power tussles, a lack of stable choristers, a lack of transparency in undertaking church programmes, inexperienced church leaders, insufficient training of personnel in training interested members in music, inexperienced worship leaders, different belief systems among church members, misinterpretation of the Scriptures by some members, secular music versus sacred music and a lack of committed and spirit-filled instrumentalists. The article analyses the data collected from oral interviews using atlas.ti coding method. The data are presented partly by way of frequency tables and charts. The study used qualitative approaches and conducted self-administered interviews on the major leaders, worship leaders or choir members and key lay members of the selected Anglican churches in Abeokuta. I used focus groups and targeted a population of 85 people in carrying out the field research. The oral interviews were conducted by way of a question and answer method using voice recording, the observation method in some cases, and by document analysis. The recording was done by the researcher, who also took notes as appropriate. The voice recording was moderated and monitored and notes were taken relating to the demeanour of the respondents. The main aim of this article was to critically examine singing and worship in Egba Diocese, Abeokuta, Nigeria, in order to see how best to advance the Gospel through its singing and worship. To arrive at this aim, the following specific objectives underpin this article:

- to study the origin or history of singing and worship in the missional context

- outline the nature and emerging trends with regard to singing and worship in the selected churches in the Diocese of Egba and Egba, Abeokuta, Nigeria.

The article presents all the narratives from my sample population of the selected churches. On the one hand, much of what we do as Christians every week is considered worship. We pray to God throughout the day. We sing hymns and songs of praise at church. More importantly, the Bible repeatedly commands us to worship God, using words like 'Praise the LORD, all nations!' (Ps 117:1). Music and singing have been a central feature of Christian worship (Ellis 2009:82). One of the many strengths that effective, successful congregations have in their worship services is congregational singing - the singing of hymns, choruses, choral responses and refrains. People learn the Christian faith as they sing the Christian hymns. The hymnal and songbook are the primary 'Bible' many people read. People discover both the content and the spirit of the gospel as they sing the hymns of mission (Callahan 1994:60). Many argue that praise songs are a key way to connect with contemporary culture and to revitalise emotional involvement in 
Christian worship. Charles H. Kraft, professor of anthropology and intercultural communication at Fuller Theological Seminary, offers a theological rationale for these songs: 'True worship ... usually takes a lot of singing to create an atmosphere of praise and worship' (Kraft 2015). This experience of worship is created significantly by the music of praise songs: 'And it is the new music, sung with eyes closed for 10,15 or $20 \mathrm{~min}$ at a time that makes that experience possible' (Ryken, Thomas \& Duncan 2003:255).

Bell (2000:67-71) offers 10 reasons why we sing. Firstly, he says it is 'because we can'. Singing is natural, like snapping your fingers or laughing at a joke. It is true that some cannot, but they usually have a sense of missing out on something which seems to come naturally to most people and most cultures. Secondly, singing helps us to express and develop group identity, as groups have particular songs they enjoy singing or which express something they believe about their community. At the same time, the rhythms of music help us to utter words together which we might find far harder to simply say together. Thirdly, singing helps express and, fourthly, trigger our emotions just as it helps us to flesh out the depth of meaning in certain words, and the association of favourite tunes with particular hymns reinforces this. Fifthly, John Bell claims that songs often evoke memories and help us to revisit the past. Then, sixthly, there are many songs which simply tell a story and tell it well. Seventhly, singing helps shape the future as it draws us into the hopes and dreams which the songs express.

John Bell (2000) comments:

Singing is a hearing and seeing and, above, all, doing activity. It requires us to take into ourselves and circulate through our system words and music which others have written and, for a shorter or longer period, to make these our own. (pp. 70-89)

Eighthly, in some cultures, singing helps people work and in worship, singing can help the congregation to share actively in the work of worshipping God. Then, ninthly, singing uses our creativity. The song is just a collection of dots and words on a page until it is brought alive through performance, and each set of musicians and each gathering of people will bring their unique combination of gifts and experiences to that performance. Finally, when we sing, we give something of ourselves. When we sing, we make ourselves vulnerable there is always the possibility that we will go out of tune and just utter a croak - and our singing is a gift of ourselves to others and to God. As we think that John Bell's 10 points all have something to contribute to our understanding, the researcher wants to reflect on just a few of them based on (Ellis 2009:88-90).

Music, and singing in particular, is advocated for teaching and admonishing one another. Therefore, the Bible is clear in stating that sacred music has an instructive purpose. There is also Biblical support for the idea that singing the word of God will strengthen our understanding of it. Singing should, in fact, be a result of hearing and meditating on God's word as well, as the psalmist said in the last section of Psalm 119:

May my lips overflow with praise, for you teach me your decrees.

May my tongue sing of your word, for all your commands are righteous.

I long for your salvation, O Lord, and your law is my delight.

Let me live that I may praise you, and may your laws sustain. (Ps 119:171-172, 174-175)

\section{Hymnody roles in worship in Anglican Communion}

The role of hymnody in worship is not limited to praise and proclamation, however. Hymns can also serve as prayers, as is the case with many of the psalms. Many passages from the psalms, canticles, hymns of Christ and various cantica minora address God directly. Direct address is one of the most recognisable characteristics of a prayer hymn. Likewise, many hymns and choruses directly address God: 'Be Thou My Vision'; 'Holy, Holy', 'My Jesus, I Love Thee'; 'Come, Thou Fount of Every Blessing'; 'Day by Day'; 'I Love You, Lord'; 'Create in Me a Clean Heart, O God' and so on. Thinking of them as anything other than prayers is simply unsupportable. One can find prayer hymns addressed to each person of the Trinity:

Father: 'Dear Lord and Father of Mankind' (John Greenleaf Whittier)

Son: 'O Jesus, I Have Promised' (John Bode)

Spirit: 'Breathe on Me, Breath of God' (Edwin Hatch)

This section for the hymnody role in worship in Liturgy of the Anglican Communion includes hymns as praise song, hymns as proclamation and music as prayer.

\section{Hymns as praise song}

A hymn is a formal song, sung to God in public worship, typically by the entire congregation. Hymns to Christ and canticles are most often hymns of praise as well (e.g. Zechariah's song: 'Praise be to the Lord, the God of Israel, because he has come and has redeemed his people'; Lk 1:68). Boice's hymn when first written was entitled 'Give Praise to God' and is based on the Pauline doxology in Romans 11:33-36. The fourth and final stanza of Boice's hymn gives us a glimpse of heavenly worship, where the new creation is singing together with heavenly beings and saints of past ages. This eternal song is quoted, and then our present response of praise is given in the refrain:

\footnotetext{
With angels, saints, and seraphim

the new creation sings,

'All glory, pow'r and praise to him

who made us priests and kings'.
}

Refrain:

All praise to Christ from grateful men for evermore. Amen. 


\section{Hymns as proclamation}

Luther realised the significant role that music could play in the spiritual growth of the Christian. He declared:

Music and notes, which are wonderful gifts and creations of God, do help gain a better understanding of the text, especially when sung by a congregation and when sung earnestly. (Odewole 2016:108)

And:

We have put this music to the living and holy Word of God in order to sing. We want the beautiful art of music to be properly used to serve our dear Creator and Christians. He is thereby praised and honored and we are made better and stronger in faith when his holy Word is impressed on our hearts by sweet music. (Odewole 2016:108)

Westermeyer (1988) expands on these statements:

Luther was not simply fond of music. Luther thought music has a theological reason for being: it is a gift of God, which comes from the 'sphere of miraculous audible things,' just like the Word of God. Music is unique in that it can carry words. Since words carry the Word of God, music and the Word of God are closely related ... It almost seems as if Luther sees music in its own right as a parallel to preaching... But the weight falls on its association with the Word and words that carry the Word. (p. 97)

Singing and music are actually meant to be a daily occupation of the believer. Luther believed that music should be composed to teach doctrine and to instruct young people that by singing the word of God, our faith would be strengthened. So did Boice (2005) in his commentary on Psalm 9:9-10, where he wrote:

It is striking that in each part the psalmist combines singing with preaching. And it is interesting to remember that great periods of church history have always been marked by both. At the time of the Reformation, Martin Luther's hymns were on the lips of the German people as much as his words were in their hearts. At the time of the Wesleyan Revival in Great Britain, the recovery of the gospel was accompanied by an equally stirring recovery of gospel singing, as the hymns of John and Charles Wesley, August Toplady, William Cowper, John Newton and others show. (p. 89)

What does the Bible witness about the instructive use of music? We know that a number of the psalms record the works of the Lord so that these might be passed on by oral tradition from priests to people and from parents to children. A New Testament statement is found in Colossians 3:16-17:

Let the word of Christ dwell in you richly as you teach and admonish one another with wisdom, and as you sing psalms, hymns and spiritual songs with gratitude in your hearts to God.

Many proclamatory hymns focus on the basic tenets of the gospel - the birth, life, death and resurrection of Christ - and the life available to us because of Christ's sacrifice. Some examples of such hymns are 'Arise, My Soul, Arise' (Charles Wesley), 'My Hope Is Built on Nothing Less' (Edward Mote) and 'Alas! And Did My Saviour Bleed?' (Isaac Watts). Personally, I define musical proclamation broadly so as to include any text that teaches or sets a passage of Scripture, recounts God's work, issues a call to repentance or reminds us of God's promises. The Boice hymn 'How Marvellous, How Wise, How Great', based on Romans 8:28-31, proclaims the cardinal doctrines of Calvinism as it reflects and expounds on this 'golden chain' passage. Its language is both proclamatory and instructive. This is not a hymn of praise, although an appropriate response to its teaching is the praise of God. Neither is it a hymn of prayer, nor a lament, nor simply a spiritual poem. It is a short sermon that outlines and explains a difficult passage of Scripture, yet it does so with poetic language and form.

\section{Music as prayer}

Prayers have been present in our singing all along (Kroeker 2005:103), but the sheer number of words and the stanzas of ordered thought tend to obscure the recognition that while we are singing, we are also praying. In many ways, the refrain form of the 19th century Gospel song and its successors, the Scripture song or chorus, provide a clearer sense of sung prayer because they are easily memorised, make use of repetition and use fewer words (Kroeker 2005:103). Sung prayer permeates the worship of many nonWestern cultures like in Anglican Communion in Abeokuta. As songs from around the world find their way into our experience, along with newer forms from intentional communities such as Iona and Taizé, some congregations are discovering what Saliars (2007:29) has called 'the integrity of sung prayer'. He states that:

At the heart of our vocation as church musicians and liturgical leaders is the question of how we enable the Church to 'pray well'- to sing and dance faithfully and with integrity ... When we are engaged in sung prayer, we are not simply dressing out words in sound; rather, we are engaged in forming and expressing those emotions which constitute the very Christian life itself. (Saliars 2007:29)

In my views, the future of vital congregational singing depends on re-establishing the link between prayer and song. Those in the Western world might learn the art of prayerful song from areas of the globe where the Christian faith is expanding vibrantly, from intentional communities of faith where prayer shapes the lives of those who live there as well as those who sojourn on pilgrimage, and liturgical traditions with deep roots in sung prayer. Kroeker (2005:107) remarks that there is also a long-standing tradition in the church suggesting that what we pray shapes our belief. To state this in the parlance of modern developmental psychology, experience or behaviour should precede the explanation. Singing is a kinaesthetic experience (Kroeker 2005:108). The entire body is the instrument of the singer; in many faith traditions, prayer also implies a specific physical posture. Each of us has learned through our varied liturgical experiences to pray in a specific manner at once mental and physical. Such a practice can lead to a monotonous, though never boring, sense of 'reverent waiting without expectation' in which one is nevertheless ready to hear the 'still small voice' of the Creator. It is in such a manner that, over time, the content of our sung prayers merges with the patterns of 
our existence and shapes our belief. According to Kroeker (2005), Albert van den Heuvel of the World Council of Churches supports this thesis clearly when he says:

It is the hymns, repeated over and over again, which form the container of much of our faith. They are probably in our age the only confessional documents which we learn by heart. As such, they have taken the place of our catechisms ... There is ample literature about the great formative influence of the hymns of a tradition on its members. Tell me what you sing, and I'll tell you who you are. (p. 127)

Sung prayer not only symbolises the unity of the church gathered, it is per se an act of unity. In this manner, it has transforming sacramental potential. Integral to music's nature to encourage unity is its ability to forge an 'enhanced group identity ... as (people) together sense similar types of affect' (Odewole 2016:127). John Blacking is more specific about the potential of music as a unifier of disparate groups within a society, as Kroeker (2005) reports:

Music can bridge the gulf between the true state of human being and the predicament of particular human beings in a given society, and especially the alienation that springs from the class struggle and human exploitation'. (p. 135)

Rather than singing only in the style of one culture, raising our voices in sung prayer with the songs of Christians around the world creates a parable of oneness in Christ. Calvin understood the singing of psalms to be prayer, which matches the teaching of the last verse of the second book of the Psalms. This concludes the prayers of David, son of Jesse (Ps 72:20). 'Spontaneous prayer only' would rule out use of the inspired Psalter. On the other hand, praying only the psalms excludes obvious New Testament passages and examples from the early church, such as the Lord's Prayer or the 'Sovereign Lord' prayer of Acts 4:23-26. Both fixed and spontaneous prayers are valid and supported by the example of Scripture. Other New Testament passages also relate singing and praying. 'Is any one of you in trouble? He should pray. Is anyone happy? Let him sing songs of praise' (Jas 5:13 - this is in the context of James's discussion of prayer and faith). ' 1 will pray with the spirit and I will pray with the mind also; I will sing with the spirit and I will sing with the mind also' (1 Cor 14:15 New American Standard Bible). Prayer and singing are closely associated with the above texts, and we see that both should be performed with the spirit (with energy, with emotion) and also with the mind (with thought). Neither element should be missing. In other words, we should mean what we pray with all our hearts and we should know what we mean. We should also mean what we sing and know what we are singing.

\section{Music and musical instruments}

In the history of civilisation, music has played a role in many spheres (Sullivan 2015). It accompanies work, provides entertainment, facilitates dancing, features in religious ceremonies and other forms of religious expression and can be used for therapeutic purposes. Music, for its own sake as an art form, is a secondary development. Speech and song are not always clearly separate, but depend on the language involved; production of words at various pitches and vocal registers can represent a form of music, so that music can arise from speech: recitation of sacral texts or prayers leads to cantillation and chant (Psalmody), used in worship without instrumental accompaniment (ibid). Rhythm is also a characteristic feature, sometimes in the articulation of sounds, but also by means of other physical forms of expression (e.g. clapping, stamping) or the use of musical instruments like drums, rattles and musical rods. Instruments make it possible to produce different notes and melodies as consciously controlled sequences of notes. Strings (e.g. harp and lyre) and winds (e.g. flute) are found almost everywhere. The culture areas concept revealed that certain types of instruments dominated particular areas based on geographical features, environment and primary occupation (King 2008:41). For example, there was a dominance of drums and drum ensembles in densely forested areas compared to those less forested, because of the availability of wood to construct the body of the drum. But more than geography was required to validate this statement. Relative to occupation, that is agriculturalists versus pastoralists, and way of life, such as nomadic or not, some cultures living in forests had no drums or the drums were borrowed from their neighbours (King 2008:41). This appeared to be true for the forest nomads of central Africa. In other cases, some instruments are played one way in one context and played differently in another (Kidula 2005:220-221). This can be read to mean that the natural and the supernatural are intertwined and related.

Music and musical instruments have frequently been associated with cosmology, because they are endowed with the power to reduce everything that exists to a (perfect) origin. As Kidula (2005:220-221) indicates, for the Florentine Renaissance thinker Marsilio Ficino (ibid), music was the master link in the cosmos, because it magically modulated the spirit as well as the world that resounds with it in systems of correspondences. Music is thus the most fluid and profound expression of the human imaginal power to reflect realities in the phantasms generated by the imagination. Even today, strings and wind instruments oriented towards these mythological sounds and notes are produced for ritual ceremonies. They play the same role: to imitate the first sounds of the mythological dawn of history, to entertain the gods and to breathe new life into the world. The religious significance of musical instruments can also be rooted mythologically in the materials from which they are fashioned. The instruments are fashioned and their sounds featured at each renewal of the generations of men and the cycles of forest life. In some ceremonies, the trumpets and flutes also become the embodiment of creative power and effective instruments of time, change, renewal and transformation (Sullivan 2015;210). The form of a musical instrument can also convey religious significance.

The rhythms of Afro-Brazilian and Afro-Cuban music are used in the cults of Umbanda, Candomblé and Santería to conjure up special supernatural beings (often figures from 
the Yoruba pantheon in Nigeria), who sometimes appear in the guise of Christian saints. Particular drums, rattles, musical gourds and rhythms call forth the supernatural powers to take possession of the bodies of the dancers (Sullivan 1997:219), but sounds and rhythms can also be used to summon such powers in order to appease them, exorcise them (Exorcism: I) or communicate with them. Sometimes, this brings on a shamanistic trance (Shamanism), during which the shaman's active participation in music and dance prepares for the journey of the soul (Sullivan 2015). But making music can also have a pastoral or therapeutic emotional dimension, serving at times - in contrast to the trance effect - to a calming, mystical immersion or outwardly invisible ecstasy, as when mantras are chanting in preparation for meditation. In the dhikr ritual of Islamic mysticism (VI), for example, rhythmic drumbeats and clapping symbolise the ceaseless repetition of the name of God (Nasr 1979).

The theology of the Dalits (a word that means 'drum', used to designate the lowest social caste) has its own religious profile. Many of the mostly poor and marginalised have converted to Christianity and refer to Christ as the 'drum' that came to deliver them and give them new life. The arrangement of participants around musical instruments during a ritual action can also be interpreted as a fundamental metaphor for the structure of society. Sullivan (1997:219) notes that social arrangements related to musical instruments thus give a religious basis to established forms of behaviour, as in the case of the Dalit drummers or the hierarchy of trumpeters and flautists among the Wakuénai. The characteristic features of an antiphony, an alternating chant between the leader and the choir, dominate in the performance of Biblical texts, as, for instance, in the Psalms. The Psalms document the tendency to provide accompaniment by string instruments; in many cases, praise of God is conducted with various instruments, as, for example, in Psalms 150. In some Biblical texts, music was also mentioned in reference to the particular situation, as, for instance, in Psalms 137, a lamentation by those in Babylonian captivity: 'How can we sing the Lord's song in a foreign land?' (Ps 137:4; ibid).

Instrumental music is possibly the least developed in the church in Africa. Missionaries initially banned almost all African instruments because they were considered pagan or associated with pagan rituals, or the playing and tuning styles were not conducive to the Christian music introduced. In addition, missionaries did not know how to play these instruments to recommend their use (Kidula 2008:108). Therefore, African instruments were publicly condemned, or new converts deemed them unsuitable because they had initially been excluded in the repertoire and stylistics introduced as Christian. The earliest instruments introduced were the organ for high churches, accordions, drums whether side drums from Salvation Army practice or African drums appropriated as signals or metric markers - and some percussion. Beginning in the late 1950s, guitars (local variants or imports) grew to be extremely popular as radio became a primary disseminator of the Christian message, and popular music from the rest of the world and different African countries gained notoriety (Kidula 2008:108). The piano was introduced in some urban churches. More recently, particularly from the 1980s, synthesisers, keyboards and soundtracks are almost commonplace in gospel music and younger generation urban churches. In some cases, African melodic instruments are introduced either as a novelty or for difference by gospel musicians, or in arrangements of African tunes or compositions by African academic elites (Kidula 2008:108). Popular or jazz band instruments have become fixtures for congregational singing. In urban areas where the congregation can afford these types of instruments, members of choirs and worship teams can and want to play them. At first, the lead, rhythm and bass guitars formed the backbone of the ensemble.

Kidula (2008:109) notes that drums were side-lined or given subordinate roles as a metronome or timeline instead of their instigating and communicative role in their parent culture groups. In some cases, new types of drums were introduced as surrogates - different in shape and technique from those in indigenous African practices. With the growth of the choral and gospel music industry, instruments such as trumpets or saxophones began to appear in music recordings or even in churches. Since the early 1990s, it is as normal to find any assortment of instruments encouraged by the pastors, priests or leaders as it is to find different types of music from a variety of sources in a church service or gathering with Christian 'overtones', such as a wedding or send-off party. The growth and development of gospel or Christian music as a commercial product has created a market for singers and instrumentalists (Abamfo 2006:142-163). The most prevalent African instruments in this music are membranophones and idiophones. The most common contemporary instrument is the guitar in its variants, but synthesisers and keyboards are part of the religious musicscape. Few instrumentalists play band, orchestral and African melody instruments in Christian religious gatherings (Kidula 2008:114).

\section{Findings}

Data were analysed and reached certain findings, the key to which is that the efforts by the evangelical churches to advance mission through music in worship is an ongoing process. Some of the ways in use by selected churches include periodical music concerts and cantata, evangelistic music campaigns, prayer groups praying for all the church activities, community hymn-singing, musical social gatherings and the family hymns specials. The respondents said that the churches were facing various problems that negatively impact the singing and worship to really have more positive effects on missions of God. Some of the respondents suggested that the churches need to enhance unity among themselves and have a proper understanding of the purpose of mission through singing and worship. I observed that the process of singing and worship in furthering the Mission of God and to advance the Gospel is very slow in the church, as only a little had been achieved by the churches. It was also apparent that there is hardly any 
proper teaching and encouragement on the impact, role, qualities and influence of Evangelistic Singing and Worship. The selected churches have internal conflicts that immensely hinder the activities of God's mission. These findings justify this article that the selected Anglican churches in Egba Diocese in Abeokuta are in dire need of a sustainable model for advancing the mission of God through singing and worship. Suffice it to say that the above findings confirm the topical nature of the problem at hand.

Worship music enters the church now in ways far different from what it was one or two generations earlier. In the age of denominations, congregational song was vetted through denominational agencies and tested for doctrinal soundness by theologians, as well as for musicality by musicians (Rienstra \& Ron 2009:89). Prior to the middle of the 19th century, musical activities in Yorubaland (where Abeokuta is situated) were mainly traditional. Although there had been some external influences on Yoruba musical life (Omibiyi 1981), they were either too minimal, or not different enough in principle from Yoruba musical tradition to precipitate a fundamental change or initiate a new idiom. It was due mainly to the arrival of returning ex-slaves from the West Indies and Brazil, and European businessmen, missionaries and colonial administrators that a social niche was created for the initiation and development of a new, European musical idiom. Before the middle of the 19th century, European contact with Nigeria, which dates back to the 15th century, was mainly on a commercial basis. Britain passed an act in 1807 which made it illegal to trade in slaves. In addition, it established a squadron with the responsibility of freeing any recaptured person found in Sierra Leone. At about the same time, freed slaves from the West Indies were settling in Freetown, the capital of Sierra Leone. Many of these freed slaves were descendants of the Yoruba people of Western Nigeria, and a good number of them chose to go back to their original home. The British assisted them and by 1850 at least 3000 thousand people had returned to settle in Badagry, Abeokuta and Lagos; they were called Saros by the local people (Omolaja 1995:15-27).

The Church Missionary Society (CMS), the largest of all such societies, established their first mission in Badagry in 1845 , and a year later in Abeokuta. Other missions included the Methodists at Badagry in 1842, the Baptists at Ijaye in 1853 and the Catholics at Lagos in 1867. The Christian missionaries were eager to spread the gospel to other parts of the country. This was only possible where peace reigned and this was far from the situation in Yorubaland, where a series of inter-ethnic conflicts were taking place. The Fon of Abomey (Adediran 1994:181-182), who lived in the presentday Republic of Benin, led a series of invasions against the Egba in Abeokuta, while two different factions (one led by Akintoye and the other by Dosumu) were struggling for the throne in Lagos.

\section{T.K. Ekundayo Phillips (1884-1969)}

It was T.K. Ekundayo Phillips who made the most significant contributions to the growth of Nigerian Church Music in the first part of 21st century. As organist and choirmaster of Christ Church Cathedral, the premier church in the Lagos Anglican Diocese, the responsibility fell on him more than any other person to encourage the growth of indigenous music in the church. He was born in 1884 and later attended the CMS Grammar School in Lagos. He received his first organ lessons from his uncle, the Reverend Johnson, and at the age of 18, he was appointed organist of St. Paul's, Breadfruit, Lagos. He played the organ at St. Paul's for 9 years. In 1911, he proceeded to the Trinity College of Music, London, to study piano, organ and violin. He thus became the second Nigerian (after Reverend Robert Coker who studied in Germany in 1871) to study music to a professional level. On his return from Britain, he was appointed organist and choirmaster at Christ Church, now Christ Church Cathedral, Lagos (Omolaja 1995:15-27).

\section{Yoruba Music}

In 1953, Phillips' book, Yoruba Music, was published. Yoruba is the language of the Abeokuta indigents. This book can be regarded as a treatise (in spite of the author's assertion to the contrary) on the compositional style of early Nigerian Church music. Although the book was not published until 1953, even after it had been published, it was not generally accessible to church organists. It summarises those ideas which have influenced Nigerian Church music composers. Central to Phillips' views are the following observations:

- Yoruba music is often based on the pentatonic scale.

- Harmony rarely exists in Yoruba music.

- Yoruba music, like all other musical traditions, is undergoing an evolutionary process.

Thus, according to him:

It is known that every nation's music has always been identified with a particular scale at various stages of its development. For example, the Europeans, as all other nations of the world, began with the pentatonic scale. This was followed by the seven-note scale with its modes, then the major minor modes and, lastly, as it stands today, the chromatic scale of twelve notes. (Phillips 1953:9)

\section{Phillips (1953) continues that:}

Fortunately or unfortunately, Yorubas have no such succession of scales yet. They have only the pentatonic scale to their credit, although at times some strange notes creep into their songs which might be regarded as the result of an instinctive feeling after variety and extension by means of embellishment. (p. 9)

Phillips asserts that Yoruba music is similar to European medieval music of 'roughly from about the tenth to the fifteenth century'. Other features which Yoruba music shares with European music are according to him:

- the use of unisonous singing

- parallel singing with its offspring of descant

- the general avoidance of cadential semitones (ibid). 
Phillips' observations are based on the belief that Yoruba music is often based entirely on the pentatonic scale and that the degree of the variety of melodic pitches employed in a piece or a tradition of music is reflective of the stage of that tradition in its developmental process. As he has also noted, features such as unisonous singing, parallel harmonics and the general absence of cadential semitones are indeed common in Yoruba music. Despite the controversial nature of Phillips' observations, they have provided the stylistic bases for much of Yoruba Church music. Phillips' works reflect a synthesis of such features of Yoruba music stated above and elements of European music. Thus, as can be observed in compositions like Emi $O$ Gbe Oju Mi Soke Wonni in Figure 1 and his Yoruba Versicles and Responses, elements of his music include the use of melodies which reflect the intonational contour of words and the use of pentatonic melodies treated to Europeanconceived diatonic chords. This stylistic paradigm has provided the basis for the development of Nigerian contemporary art and church music.

\section{Demographic information: Distribution of respondents according to churches in Egba and Egba West Dioceses, Abeokuta}

Table 1 summarises the information obtained from the respondents.

The information in Table 1 was received from various church leaders on various dates during the interviews. The table shows that when one looks at distribution according to churches, $26 \%$ belong to the CCA, $24 \%$ to the CCI, $20 \%$ to SJCI, $16 \%$ to ASCI and $14 \%$ to SACI.

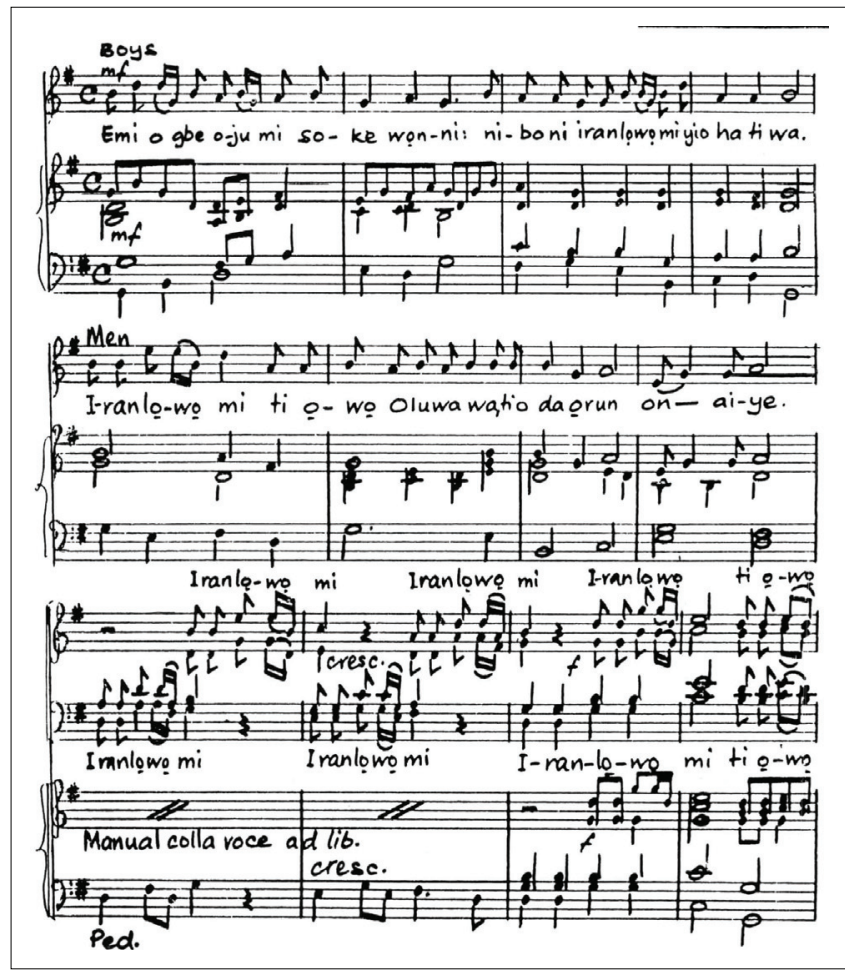

Source: Phillips, T.K.E., 1953, Yoruba Music, p. 9, Johannesburg, viewed n.d., from http:// books.openedition.org/ifra/docannexe/image/609/

FIGURE 1: Emi o gbe oju mi soke wonni by T.K.E. PHILLIPS
TABLE 1: Distribution of the respondents according to churches in Abeokuta.

\begin{tabular}{|c|c|c|c|c|}
\hline Churches & $\begin{array}{l}\text { Church Member } \\
\text { Group - CMG }\end{array}$ & $\begin{array}{c}\text { Church } \\
\text { Focus Group } \\
\text { - CFG }\end{array}$ & $\begin{array}{c}\text { Frequency of } \\
\text { Respondents- } \\
\text { FR }\end{array}$ & $\%$ \\
\hline $\begin{array}{l}\text { The Cathedral Church, Ake } \\
\text { (CCA) }\end{array}$ & 2 & 7 & 13 & 26 \\
\hline $\begin{array}{l}\text { The Cathedral Church, } \\
\text { Igbore (CCl) }\end{array}$ & 2 & 6 & 12 & 24 \\
\hline $\begin{array}{l}\text { St. John's Church, Igbein } \\
\text { (SJCI) }\end{array}$ & 2 & 5 & 10 & 20 \\
\hline $\begin{array}{l}\text { All Saints' Church, Itoku } \\
\text { (ASCI) }\end{array}$ & 2 & 4 & 8 & 16 \\
\hline $\begin{array}{l}\text { St. Andrew's Church, Ibara } \\
\text { (SACI) }\end{array}$ & 2 & 3 & 7 & 14 \\
\hline Total & 10 & 25 & 50 & 100 \\
\hline
\end{tabular}

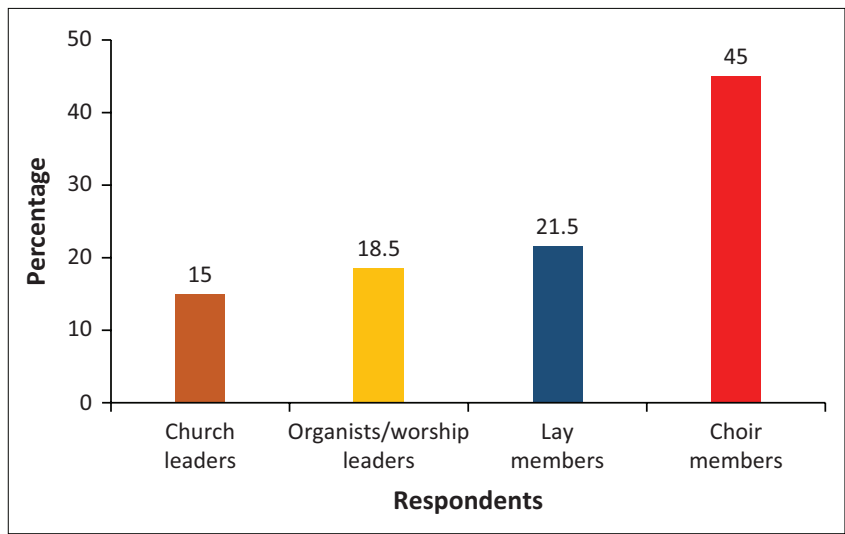

FIGURE 2: Distribution of respondents according to position in the church.

Figure 2 indicates that, when categorised according to status in the church, the majority (45\%) comprised the Church Choristers' membership (male and female), 21.5\% were lay members of the church and $18.5 \%$ were the Worship leaders or Organists, while 15\% were church leaders. The low figures on the participation of church leaders in mission create a paradox, because such leaders should be the custodians of liturgy and worship in seeking to fulfil the church's responsibility in leading the Church Worship.

I have structured the data according to topical headings that were identified as relevant to the narratives. These are: background and history, liturgical involvement, singing or musical style and organisation and closing reflection. These four headings were not disclosed to the participants. This allowed for a comfortable conversation with all participants during the interview process. The closing reflection is my own synopsis on the relevant headings during the conversation. Including all the material that was narrated during the interviews would be a cumbersome task for the purpose of this article.

\section{A case for the Egba Diocese in Abeokuta, Anglican Communion - Church of Nigeria}

- Demography: Urban, Abeokuta Metropolis

- Worship style:Traditional,Contemporary,Contemplative, Evangelical or Charismatic and Low Church

- Participants: The clergy, Organists, Choristers and musicminded laity 


\section{Background and history}

As deduced from a respondent, the Anglican Church is a church with a long history and it takes its past seriously. But it is also rooted in the present time in the local place. As part of the Church of God universal, the Anglican Communion is designed by divine inspiration to operate in line with God's standards, as clearly stated in the Bible. The Anglican Church in Abeokuta was started as far back as 1843 by The Revd Henry Townsend, while other churches in the Anglican Communion in the western part of Nigeria began to spring up through the efforts of The CMS. The growth of the Church of Nigeria (Anglican Communion) since the end of the Slave Trade has been a very rapid one. It is interesting to note that within two centuries, Christianity and indeed Anglicanism, which started like child's play in Badagry and Abeokuta, has spread like wild fire to all nooks and crannies of Abeokuta and the country as a whole.

Christianity came into Nigeria in the 15th century through the efforts of Augustinian and Capuchin monks from Portugal. However, it was not until 1842 that Henry Townsend of the CMS sowed the seed of Anglicanism properly when he landed in Badagry from Freetown, Sierra Leone. After their ordination in England in 1842, the Revd Henry Townsend and the Revd Samuel Ajayi Crowther (a Yoruba ex-slave) returned to Abeokuta. With the untiring efforts of these evangelists, Nigerians began to believe in Jesus as the Lord and Saviour of the entire world. And so, on 25 December 1842, in Abeokuta, Nigerians were able to celebrate for the very first time the glorious annunciation that the Saviour, who is Christ the Lord, was born. They gave glory to God Almighty, experiencing the peace and joy of the Lord; Anglicanism had been born in Nigeria. In 1846, the Revd Samuel Ajayi Crowther and the Revd Henry Townsend, in company with the Revd Colmer and Mr Phillips, worked together to consolidate the CMS's Yoruba Mission (History of Anglicanism 2015).

\section{Liturgical involvement of the Egba and Egba West Dioceses - Anglican Communion}

In the Anglican Church public worship, 'liturgy' is the term we use for all the church's sacramental rite and texts. Armentrout and Slocum (2000:47) opine that 'liturgy expresses the church's identity and mission, including the church's calling to invite others and to serve with concern for the needs of the world'. Liturgies of the Anglican are in the Book of Common Prayer. Singing in the church can be as diverse as its worship services. The final authority over the music used in an Anglican worship service is 'the duty of every Clergy' (Canon 24, Section 1), our hymnal draws all members together musically in the same way that the Book of Common Prayer draws us together in prayer and liturgy. The Anglican Church serves God's 'divine plan for the fullness of time, to unite all things in Christ, things in heaven and things on earth'. By now the Church of Nigeria (Anglican Communion) had been proclaimed by the Archbishop of Canterbury as 'the fastestgrowing church in the Anglican Communion!' Forging ahead vigorously, there can be no organisation as large and as complex as the present-day Church of Nigeria (Anglican Communion) that is without problems.
In summary, it is to the effect that the Church of Nigeria (Anglican Communion) shall be Bible-based, spiritually dynamic, united, disciplined, self-supporting, committed to pragmatic evangelism, social welfare and a church that epitomises the genuine love of Christ. The Anglican Church operates in accordance with God's Great Commission in Matthew 28:16-20 to all believers: every aspect of its life and work, its faith and order, point to, reveal, announce and serve 'the mystery of missio Dei', as noted by a respondent. The Church of Nigeria is likely the largest in the Anglican Communion in terms of membership. Abeokuta in Nigeria was first evangelised by Anglican missionaries of the CMS in 1842 , and to this day maintains the evangelical character typical of areas where the CMS was active. The Anglican Church in Nigeria used the 1662 BCP (plus, of course, translations of it into indigenous languages) up until the independent Province of Nigeria was created in 1979. Nigeria approved a Book of Common Prayer of its own in 1996, from which this booklet presumably was taken (The Liturgy of the Church of Nigeria 2017). Okeke (2008), in an essay on the BCP in Nigeria, in The Oxford Guide to the Book of Common Prayer, states that the 1996 Nigerian BCP 'on the whole relies on adoption and adaptation rather than on liturgical creativity and innovation'.

\section{Singing or musical style and organisation}

A respondent said that music per se in the Anglican Church is part and parcel of its worship. Many times, worship proper does not begin without praising the person you want to commune with, you know who God is and that He likes and enjoys being worshipped and praised, so most times, before any worship proper begins, praise worshipping and singing of songs are the first steps after which one can go into other areas of worship. Most times they find their minds ready for worship when they start with singing songs and praises. Anglican Church music is the music that is written for liturgical worship in Anglican Church services. Almost all of it is written for choir, with or without organ accompaniment. Another respondent noted that, guiding the forefathers to put together the 39 Articles of Religion that form the core of the tenets of what is believed and practised in the Anglican Communion, each of the Articles is firmly rooted in the Bible. He went on to say that their hymns are divinely inspired and suitable for worship, individually or corporately. This is well acknowledged, appreciated and enshrined, in practice, in the Anglican Communion, and that enables the church to fulfil its mandate as they make themselves available for service at different levels in the church.

There is now the understanding that exuberance and devotion can go hand in hand for enriched, acceptable and profitable music in worship, individually and corporately. As recorded from a respondent, before now there was strict control, if not total rejection, of Davidic exuberance in music in worship - for instance, the shout of 'Halleluyah!' as part of singing in worship was frowned at, whereas true music in worship should be characterised by delight, rejoicing and dancing when we are excited about our deliverance from sin's bondage, coupled with our consciousness of the free 
access we now have to the only Eternal God. Apart from the central place held by liturgy, there are other texts that have strongly influenced their church, as noted by a respondent, and especially important are hymns. He said further that the Psalms were Anglicanism's first hymns, and at the Reformation were added Metrical Psalms written with strict rhythm and rhyme to accompanying simple melodies; the Eucharistic Hymns now in various languages of the worshippers and to simple music; and the Biblical and early church hymns of the Daily Offices like the Venite (Ps 95), the Nunc Dimittis (Lk 2) and the Te Deum Laudamus. To sing parts of the liturgy is a typically Anglican thing to do. We can note in Figure 3 the classical Anglican choir handling the abovenoted Daily Offices in all liturgical services, while Figure 4 shows a contemporary Anglican choir handling all evangelical programmes.

\section{Closing reflection}

One respondent said, 'The Church of Nigeria, Anglican Communion's music in worship in the church successfully combines devotion with delight. Members of the Church are encouraged to rejoice in the Lord always. Moreover, there is a justifiable balance between Davidic exuberance and worship to the only true God. The entire gospel of Jesus Christ is constantly preached through our music'. Congregations can be led to understand the primary purpose of music in worship. Their knowledge concerning congregational music can be increased because congregations should not be willing to settle for their present level of music and worship. As noted by a respondent, the church needs to sustain the understanding of the current state of our music in worship. It is therefore suggested that the preaching of the gospel and the teaching of the word of God through our music should be prayerfully intensified. Anglican music in the early 21st century finds itself with more glorious variety than at any other time in its history. At the same time, diversity expands at a challenging pace. Because of Anglican Church music expanding in diversity, defining its music is increasingly difficult. However, Anglican music in all its rich diversity - historic and contemporary, traditional and

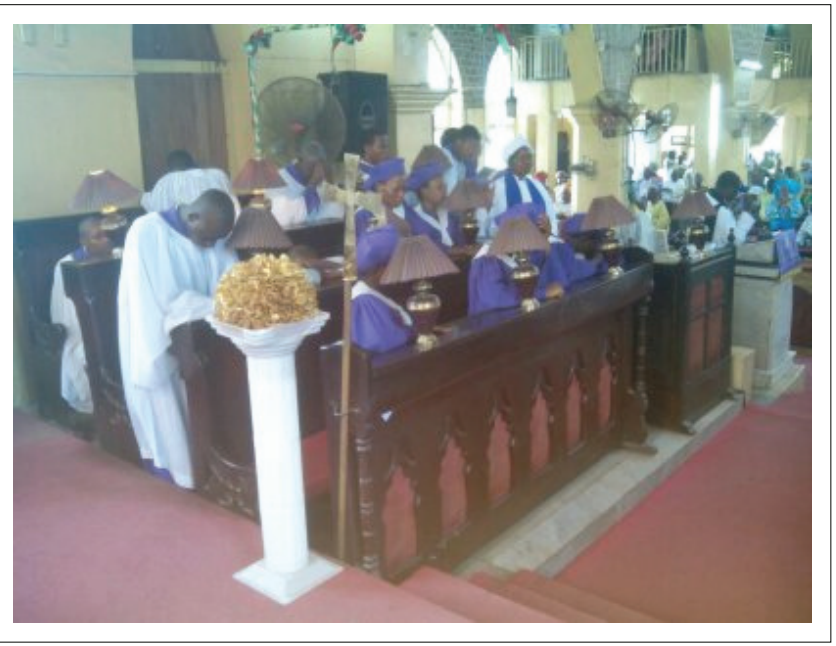

Source: Photo taken by author

FIGURE 3: Classical Anglican choir handling all liturgical services.

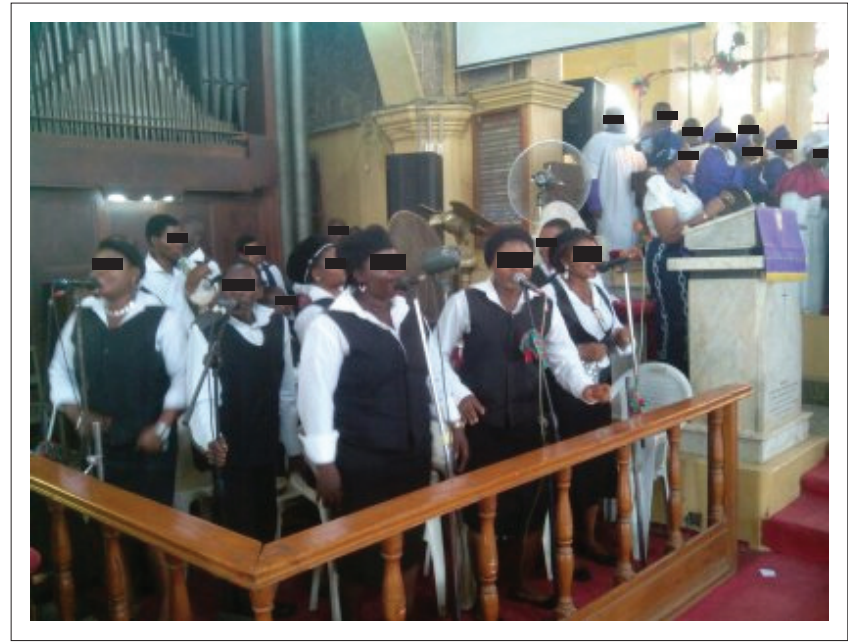

Source: Photo taken by author

FIGURE 4: Contemporary Anglican choir handling all evangelical programmes.

innovative - continues to attract new worshippers and blesses the people of God. This is very important both for the experience of the worshippers, as they do something communally, and for those who are leading and planning worship. Singing helps people say something together - to praise together, to give thanks together, to celebrate or confess together. It is no wonder that congregational singing has increased as a proportional part of worship services in many churches in recent years.

\section{Conclusion}

The church has had a significant impact upon singing and worship. It has caused churches to give much more careful consideration to how much of their music in worship methodology has been shaped by culture rather than Scripture, and how they can recover believers' worship that had been lost in many churches' evangelistic restructuring, while nevertheless making worship intelligible to unbelievers. Therefore, the full correction of errors regarding singing and worship and evangelism that missional advocates rightly identify requires a more careful study of culture and worship and their relationship to evangelism from a Biblical perspective. For centuries, ordinary Christians have often found themselves expressing their faith by quoting hymns. It is as though the combination of poetry and music reaches deeper into their emotional engagement with the spiritual realities that are being described or expressed than prose (ordinary sentences) can ever do. The worshippers are encouraged not only to contemplate the wonderful redemption made possible through the death of Christ, but also to proclaim and reflect upon the wonder of God being on the cross. This is very important both for the experience of the worshippers, as they do something communally, and for those who are leading and planning worship. Singing helps people say something together - to praise together, to give thanks together, to celebrate or confess together. It is no wonder that congregational singing has increased as a proportional part of worship services in many churches in recent years. 
How much more powerful and involving is this than saying it in descriptive prose and, when it is sung with a strong and enjoyable tune, there can be a great sense of communal rejoicing. Singing has this capability of touching hearts as well as minds in communal worship.

God's power is the power of the cross and the power of love. If God avoids coercion and manipulation, so should we. There is a fine line between using music in a way that provides support and atmosphere, and using it to play on the emotions and making people to do things which they would not otherwise do. The ends do not justify the means, even when people seem to be coming to faith for the first time. Song-writing is clearly a very creative activity, both in forming the lyrics and composing the music. But much creativity is also in evidence when songs are performed. Many congregations will have musicians who, either singly or, more commonly, as groups, contribute to the worship of the community. Again, there are a couple of health warnings. People often feel strongly about music and you need to have built a relationship of trust and mutual respect with the musicians if you are sometimes to negotiate a constructive way through potential disagreements. Singing has been an important aspect of our behaviour throughout time and, in one way or the other, it encourages our giving life. We have enjoyed and used singing in various ways for a very long time; this is simply because each of us has a tendency to react and connect to the singing of others, to varying degrees and in varying ways.

\section{Acknowledgements \\ Competing interests}

The author declares that he has no financial or personal relationships which may have inappropriately influenced him in writing this article.

\section{References}

Abamfo, A., 2006, 'Singing with understanding: A study of Gospel music in Ghana', Studies in World Christianity 12(2), 142-163.

Adediran, B., 1994, The frontier states in Western Yorubaland 1600-1889, IFRA, Ibadan, pp. 181-182.

Armentrout, D.S. \& Slocum, R.B., 2000, An Episcopal dictionary of the church: A userfriendly reference for Episcopalians, Church Publishing INC, New York.

Bell, J.L., 2000, The singing thing: A case for congregational song, Wild Goose Publications, Glasgow.

Boice, J.M., 2005, Psalms Volume 1: Psalms 1-41 (An Expositional Commentary), Baker Books, Grand Rapids, MI.

Callahan, K.L., 1994, Dynamic of worship: Mission, grace, praise and power, JosseyBass Publishers, San Francisco, CA.

Ellis, C., 2009, Approaching God: A guide for worship leaders and worshippers, Canterbury Press, Norwich.

History of Anglicanism, viewed 23 October 2015, from http://www. dioceseoflagoswest. org/Doctrine/History.html

Kidula, J.N., 2005, Music in Kenyan Christianity: Logooli religious song, Indiana University Press, Bloomington, IN.

King, R.F., 2008, 'Music', in W. Dyrness \& V.-M. Kårkåinen (eds.), Global dictionary of theology, pp. 130-142, InterVarsity Press, Downers Grove, IL.

Kraft, C.H., 2015, Worship: Beyond the Hymnbook, Christian Today, Eugene, OR.

Kroeker, C. (ed.), 2005, Music in Christian Worship: At the service of the liturgy, Liturgical Press, Collegeville, MN.

Nasr, S.H., 1979, 'Islam and music: The legal and the spiritual dimensions', Studies in Comparative Religion 10(1).

Odewole, I.O.O., 2016, 'Missional character of music in worship', Doctoral thesis, UNISA.

Okeke, D., 2008, in C. Hefling \& C. Shattuck (eds.), The Oxford guide to the book of common prayer: A worldwide survey, Oxford University Press.

Omibiyi, M., 1981, 'Islamic influence on Yoruba Music', African Notes 8(2).

Omolaja, B., 1995, Historical background of modern Nigerian art music, Institut français de recherche en Afrique, pp. 15-27, viewed 10 November 2015, from http://www.openedition.org/6540

Phillips, T.K.E., 1953, Yoruba Music, p. 9, Johannesburg, viewed n.d., from http:// books.openedition.org/ifra/docannexe/image/609/

Rienstra, D. \& Rienstra, R.on, 2009, Worship words: Discipling language for faithful ministry, BakerAcademic, Grand Rapids, MI.

Ryken, P.T.D. \& Duncan, J., III (eds.), 2003, Give praise to God, P\&R, Phillipsburg.

Saliars, D.E., 2007, Music and theology, Abingdon Press, Nashville, TN.

Sullivan, L., 2015, Music and musical instruments, Religion Past and Present, Brill Online, Reference, University of South Africa, viewed n.d., from http:// referenceworks.brillonline.com/entries/religion-past-and-present/music-andmusical-instruments-COM_14614\

The Liturgy of the Church of Nigeria, viewed 21 February 2017, from http://justus. anglican.org/resources/bcp/Nigeria/Nigeria_hc.htm

Westermeyer, P., 1988, The church musician, Harper \& Row, San Francisco, CA 